\title{
STRESS FAILURE OF CEMENT CONCRETES UNDER COMPRESSION - SYNTHESIS OF KNOWLEDGE, CONCLUSIONS
}

\author{
Tomasz GORZELAŃCZYK, Jerzy HOŁA \\ Institute of Building Engineering, Wrockaw University of Technology, \\ Wybrzeże Wyspiańskiego 27, 50-370 Wrocław, Poland \\ Received 16 Jan 2014; accepted 22 May 2014
}

\begin{abstract}
This paper presents a synthetic review of the existing knowledge on the stress failure of cement concretes under compression, based on the available literature and the authors' own research. It is pointed out that there is no knowledge on the stress failure of new-generation concretes, which needs to be acquired through proper research. The usefulness of the knowledge on the stress failure of concrete under compression for building practice is highlighted.
\end{abstract}

Keywords: ordinary concrete, special concrete, stress failure, initiating stress, critical stress, acoustic techniques, fatigue strength.

\section{Introduction}

The problem of the stress failure of concrete subjected to compression covers the initiation, evolution, accumulation and propagation of microcracks in the concrete structure under an external load. The course of stress failure depends on the presence of various internal stresses and defects initiated when the concrete was not under the load (Beres 1971b; Flaga 1993, 1995; Hsu et al. 1963; Khatib, Mangat 1999; Newman, K., Newman, J. 1971). It is thought that the stresses and the defects stem from a whole range of technological factors involved in the broadly understood process of concrete making and that they have a decisive influence on the course of the stress failure of the concrete, manifesting itself in cracking initiating stress $\sigma_{i}$ and critical stress $\sigma_{c r}$ in laboratory tests (Beres 1971b; Flaga 1993, 1995; Hoła, Ranachowski 1992; Hoła 2002; Hsu et al. 1963; Khatib, Mangat 1999; Newman, K., Newman, J. 1971).

Many researchers regard cracking initiating stress $\sigma_{i}$ and critical stress $\sigma_{c r}$ as the two key strength characteristics of concrete under compression, indicating its predisposition to signalled or unsignalled cracking (Beres 1971a; Flaga, Furtak 1982; Furtak 1997; Hoła 2000b, 2002; Hsu 1981). The interest in exploiting these stresses in the assessment of the destructive processes taking place in concrete under compression is far from waning (Furtak 2002; Gorzelańczyk 2007; Goszczyńska 2014; Hoła 1994, 2000b; Moczko 1996; Ranachowski et al. 2010, 2012; Stroeven, Moczko 1996) and covers the ever new concretes, including special concretes (Błaszczyński et al. 2008; Gorzelańczyk 2007; Hoła 1998, 2000a, b; Przybylska-Fałek 2013).
The aim of this paper was to provide a synthetic review of the existing knowledge on the stress failure of cement concretes under compression. The review is based not only on literature reports, but also on the results of extensive studies carried out by the present authors (Gorzelańczyk 2007; Hoła 2000b). It is indicated that there is a lack of knowledge on the stress failure of new generation concretes and that it should be made up for through research. The usefulness of the knowledge on the stress failure of concrete under compression in building practice is highlighted.

\section{Stress failure of ordinary concrete}

The stress failure of ordinary concrete under compression has been the subject of numerous studies and has been fully explored. It has been demonstrated that the failure of this concrete under a momentary compressive load is a three-stage process (Beres 1971b; Flaga, Furtak 1981, 1982; Hoła 2000a, b; Moczko 1991; Ngab et al. 1981; Perry, Gillott 1977; Stroeven, Moczko 1996). The stages are: the stable initiation of microcracks, the stable evolution and propagation of the microcracks and the unstable propagation of the microcracks (Beres 1971b; Flaga, Furtak 1982; Hoła 1992a, 2000b; Hsu et al. 1963; Moczko et al. 1995; Ranachowski 1990, 1991; Stroeven, Moczko 1996). The above stages demarcate the levels of cracking initiating stress $\sigma_{i}$ and critical stress $\sigma_{c r}$.

Tests show that in ordinary concretes under compression the cracking initiating stress and the critical stress may reach different levels. This may be due to different technological factors and the concrete making conditions as well as to nonmechanical service factors, such as the ones shown in Figure 1. 


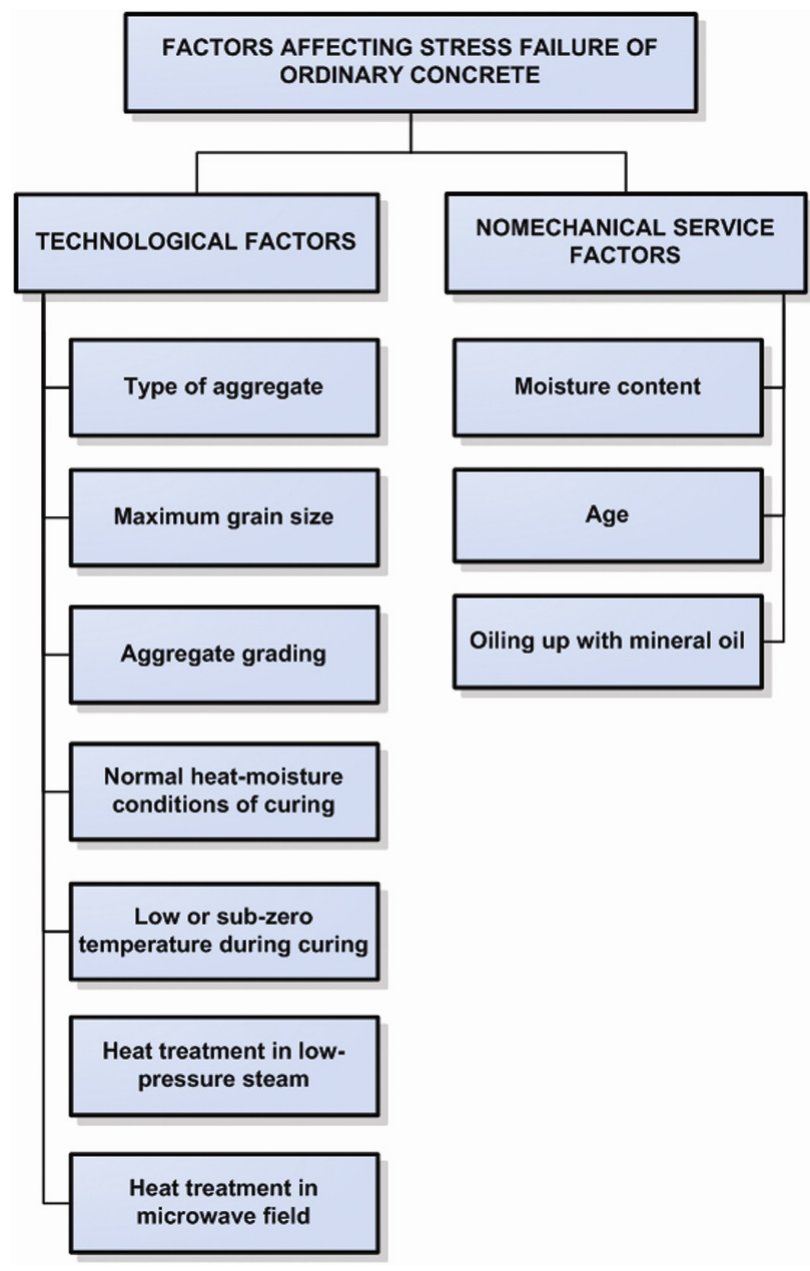

Fig. 1. Major technological and nomechanical service factors affecting stress failure of ordinary concrete under compression

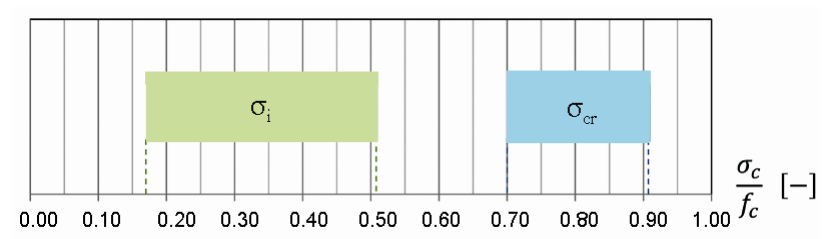

Fig. 2. Ranges of levels of cracking initiating stress $\sigma i$ and critical stress $\sigma \mathrm{cr}$ in ordinary concretes subjected to various technological and nonmechanical service factors

The relative levels of cracking initiating stress $\sigma_{i}$ and critical stress $\sigma_{c r}$ depending on various technological and service factors acting on ordinary concrete under compression are presented in Table 1 (Błaszczyński 2011; Błaszczyński et al. 2008, 2009; Broniewski et al. 1994; Flaga, Furtak 1981, 1982; Furtak 1997; Gorzelańczyk 2011; Hoła 1992a, b, 1994, 1996a, b, 2000b, 2002; Hoła, Ranachowski 1992; Hsu et al. 1963; Moczko 1991; Moczko et al. 1995; Newman, K., Newman, J. 1971). It appears that the relative levels of cracking initiating stress $\sigma_{i}$ and critical stress $\sigma_{c r}$ range widely. And so stress $\sigma_{i}$ is in a range of $0.17-0.60 \sigma_{c} / f_{c}$ and stress $\sigma_{c r}$ is in a range of $0.66-0.91 \sigma_{c} / f_{c}$, as illustrated in Figure 2.

\section{Stress failure of special concretes}

This section presents the results of investigations into the stress failure of special concretes selected from the ones most commonly used in construction. The concretes were investigated using the acoustic techniques of acoustic emission and ultrasonic emission since these techniques have been found to be particularly useful for studying the stress failure of concrete under compression (Furtak 2002; Gorzelańczyk 2011; Goszczyńska 2014; Hoła 1994, 2000a, b; Moczko 1991; Moczko et al. 1995; Ranachowski 1991, 1997; Ranachowski et al. 2012; Stroeven, Moczko 1996). The AE descriptors usually recorded are: the $\mathrm{AE}$ counts sum, the rate of $\mathrm{AE}$ events and the RMS signal. The levels of cracking initiating stress $\sigma_{i}$ and critical stress $\sigma_{c r}$ are determined on the basis of the above descriptors in accordance with the criteria specified in Gorzelańczyk (2007), Hoła (1994, 2000b), Przybylska-Fałek (2013). In the case of the ultrasonic technique, the velocity of longitudinal ultrasonic waves $\left(V_{L}\right)$ versus the increment in compressive stress is the recorded descriptor (Flaga, Furtak 1982; Furtak 2002; Gorzelańczyk 2011; Hoła 1992a, 1996a, 2000a, b; Moczko 1991). The criteria for determining the levels of stresses $\sigma_{i}$ and $\sigma_{c r}$ by means of this technique are given in Gorzelańczyk (2007), Hoła (2000b), Moczko (1991). Exemplary schematics of the test rigs and views of specimens being investigated using the acoustic techniques can be found in Gorzelańczyk (2007) and Hoła (2000b).

\subsection{Polymer impregnated concrete}

Polymer impregnated concrete (PIC) is obtained by impregnating hardened concrete with a monomer or a propolymer, which then undergoes polymerization inside the concrete. This composite is characterized by very high compressive and tensile strength and consequently by markedly increased tightness, manifesting itself in an about fifteen-fold decrease in water absorption in comparison with unimpregnated concrete (Czarnecki 2009; Czarnecki, Łukowski 2002; Neville 2000).

Literature reports (Broniewski et al. 1994; Hoła 2000b, 2002) indicate that the level of cracking initiating stress $\sigma_{\mathrm{i}}$ in polymer impregnated concrete cannot be explicitly determined, whereas in the reference unimpregnated concrete this level amounts to $0.50 \sigma_{\mathrm{d}} / f_{\mathrm{c}}$. This is due to the fact that the failure of the concrete structure strengthened with polymer inclusion takes place not in three, but rather in two stages. In the first stage of this process, covering a stress range of $0-0.90 \sigma_{\mathrm{c}} / f_{\mathrm{c}}$, a cascading effect is observed using the $\mathrm{AE}$ technique. This effect markedly intensifies beginning with the stress level of $0.55 \sigma_{\mathrm{c}} / f_{\mathrm{c}}$, indicating the occurrence of several stress levels in the interval of $0.55-0.90 \sigma_{\mathrm{c}} / f_{\mathrm{c}}$, which could be regarded as initiating. At these levels the momentary stable propagation of microcracks and the momentary rapid propagation of the microcracks take place. The upper limit of this interval corresponds to critical stress $\sigma_{\mathrm{cr}}$. The level of this stress, amounting to $0.90 \sigma_{\mathrm{c}} / f_{\mathrm{c}}$, is higher than in the reference unimpreganted concrete, where it amounts to $0.80 \sigma_{\mathrm{c}} / f_{\mathrm{c}}$. The above findings are illustrated in 
Table 1. Relative levels of cracking initiating stress $\sigma_{i}$ and critical stress $\sigma_{c r}$ for various technological and nonmechanical service factors acting on ordinary concrete under compression

\begin{tabular}{|c|c|c|c|c|c|}
\hline \multirow{2}{*}{\multicolumn{3}{|c|}{ Technological and service conditions }} & \multirow[t]{2}{*}{ Researchers } & \multicolumn{2}{|c|}{$\begin{array}{c}\text { Relative levels of stress } \sigma_{i} \\
\text { and } \sigma_{c r}\end{array}$} \\
\hline & & & & $\sigma_{i} / f_{c}$ & $\sigma_{c r} / f_{c}$ \\
\hline \multicolumn{3}{|c|}{ Normal heat-moisture conditions of curing } & (Flaga, Furtak 1981, 1982; Hoła 2000b) & $0.46-0.51$ & $0.80-0.88$ \\
\hline \multicolumn{3}{|c|}{ Air-dry heat-moisture conditions of curing } & (Flaga, Furtak 1981, 1982; Hoła 2000b) & $0.40-0.46$ & $0.70-0.81$ \\
\hline \multicolumn{3}{|c|}{ Full saturation with water } & (Hoła 2000b) & $0.20-0.30$ & 0.90 \\
\hline \multicolumn{3}{|c|}{ Drying to fully dry condition, at $105^{\circ} \mathrm{C}$} & (Hoła 2000b) & 0.30 & $0.80-0.82$ \\
\hline \multicolumn{3}{|c|}{ Low or sub-zero temperatures during curing } & (Flaga 1993) & $0.17-0.23$ & $0.71-0.75$ \\
\hline \multicolumn{3}{|c|}{ Heat treatment in low-pressure steam at $<80^{\circ} \mathrm{C}$} & (Hoła 1992b, 1996a) & $0.36-0.41$ & $0.81-0.90$ \\
\hline \multicolumn{3}{|c|}{ Heat treatment in low-pressure steam at $\geq 80^{\circ} \mathrm{C}$} & (Hoła 1992b, 1996a) & $0.34-0.35$ & $0.76-0.91$ \\
\hline \multicolumn{3}{|c|}{ Heat treatment in microwave field } & (Hoła 2000b, 2002) & 0.37 & 0.83 \\
\hline \multicolumn{3}{|c|}{ Hot forming at $45^{\circ} \mathrm{C}$} & (Hoła 2000b, 2002) & 0.41 & 0.81 \\
\hline \multirow{3}{*}{ Type of aggregate } & \multicolumn{2}{|c|}{ rounded } & \multirow{3}{*}{$\begin{array}{l}\text { (Beres 1971b; Flaga, Furtak 1981; } \\
\text { Furtak 1997; Hoła 1992a, 2000b) }\end{array}$} & $0.41-0.50$ & $0.70-0.83$ \\
\hline & \multicolumn{2}{|c|}{ limestone } & & 0.51 & 0.88 \\
\hline & \multicolumn{2}{|c|}{ basalt } & & 0.45 & 0.80 \\
\hline \multirow{5}{*}{ Aggregate grading } & $20 \%$ & ntent $\leq 37.5 \%$ & (Hoła 1992a, 2000b) & $0.40-0.45$ & $0.70-0.81$ \\
\hline & 37.5 & content $\leq 47.5 \%$ & (Hoła 1992a, 2000b) & $0.40-0.50$ & $0.81-0.82$ \\
\hline & 47.5 & content $\leq 60 \%$ & (Hoła 1992a, 2000b) & 0.50 & $0.82-0.83$ \\
\hline & $60 \%$ & ntent $\leq 85 \%$ & (Hoła 1992a, 2000b) & $0.34-0.50$ & $0.83-0.85$ \\
\hline & $85 \%$ & ntent $\leq 100 \%$ & (Hoła 1992a, 2000b) & $0.24-0.34$ & $0.85-0.90$ \\
\hline \multicolumn{3}{|c|}{ Condition of aggregate surface } & (Perry, Gillott 1977) & $0.40-0.50$ & $0.83-0.86$ \\
\hline \multirow{2}{*}{\multicolumn{2}{|c|}{ Age of concrete }} & below 28 days & (Moczko 1991; Moczko et al. 1995) & $0.20-0.30$ & $0.76-0.80$ \\
\hline & & above 28 days & (Moczko 1991; Moczko et al. 1995) & $0.30-0.45$ & $0.76-0.80$ \\
\hline \multicolumn{3}{|c|}{ Oiling up with mineral oil } & (Błaszczyński 2011; Hoła 1996b) & $0.30-0.40$ & $0.75-0.80$ \\
\hline
\end{tabular}

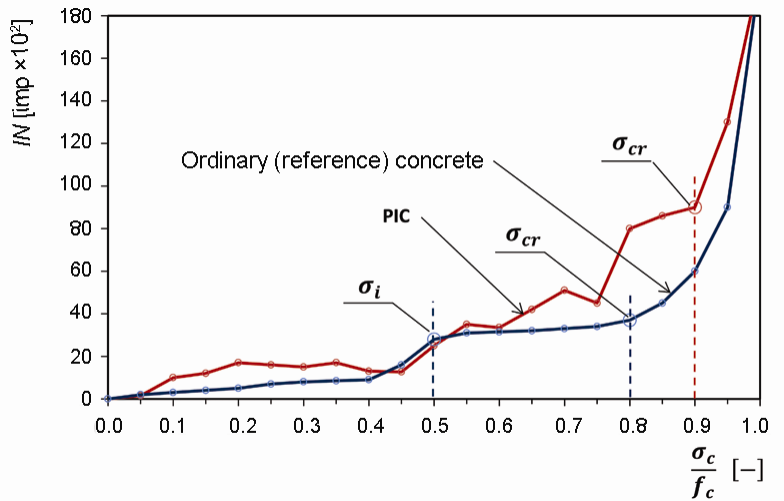

Fig. 3. Rate of AE counts sum increment in PIC and in reference unimpregnated concrete, under compression, versus increment in relative stress value (Hoła 2000b)

Figure 3 which shows the diagram of the rate of $\mathrm{AE}$ counts sum increment in the reference concrete and in the polymer impregnated concrete, subjected to compression, versus increment in the relative stress value (Hoła 2000b).

The test results indicate that the strengthening of concrete with polymer inclusion has a beneficial effect on the failure processes. As shown in Czarnecki (2009) and Czarnecki and Lukowski (2002), the mechanisms of this strengthening consists in:

- a reduction in stress concentration in places where defects and structural discontinuities occur, owing to the filling of the discontinuities with the polymer;
- an increase in the load-bearing capacity of the hardened cement paste as a result of the consolidation of its crystalline skeleton;

- the formation of polymer bridges in the larger pores of the hardened cement paste, having a inhibiting effect on the propagation of cracks;

- an increase in the adhesion of the hardened cement paste to aggregate grains as a result of the filling of voids and pores in the intermediate layer and in the cement paste with the polymer and the strengthening of the hardened cement itself.

\subsection{Fibre-reinforced concrete}

Fibre-reinforced concrete contains usually steel fibres, less often glass, aramid or polypropylene fibres (Błaszczyński et al. 2008, 2009; Neville 2000; Stroeven, Moczko 1996). Because of its advantageous mechanical properties and high durability fibre-reinforced concrete is widely used in transport infrastructure and industrial building construction (Błaszczyński et al. 2008, 2009; Neville 2000).

The studies carried out in Błaszczyński et al. (2008, 2009), Przybylska-Fałek (2013) showed that the failure of concretes containing steel fibre reinforcement does not take place in three stages as in the case of ordinary concrete. There is some similarity between the failure of fibre-reinforced concrete and that of polymer impregnated concrete, but no such a marked cascading effect is observed (Broniewski et al. 1994; Hoła 2000b). 


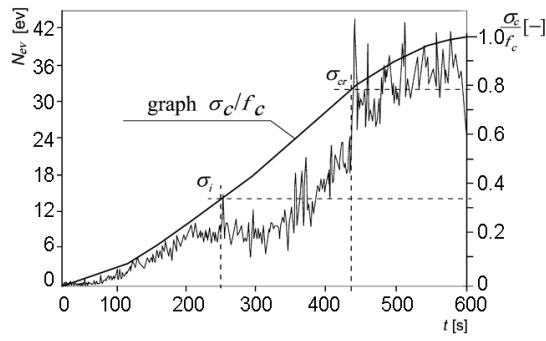

a)

Fig. 4. Rate of AE events ( $\left.N_{e v}\right)$ versus failure time for fibre-reinforced concrete: a) not containing steel fibres (SF); b) containing $1 \%$ of steel fibres (F1), c) containing 3\% of steel fibres (F3) (Błaszczyński et al. 2008; Przybylska-Fałek 2013)

Figure 4 shows the recorded rate of $\mathrm{AE}$ events $\left(N_{\mathrm{ev}}\right)$ versus compression time for two fibre-reinforced concretes with a steel fibre content of respectively $1 \%$ (F1) and $3 \%(\mathrm{~F} 3)$ relative to the mass of the concrete and for a reference concrete (SF) without such fibres. The diagrams include a graph of the increment in relative compressive stress value $\sigma_{c} / f_{c}$ versus failure time.

An examination of the recorded rate of $\mathrm{AE}$ events in Figures $4 \mathrm{~b}$ and $4 \mathrm{c}$ reveals that the presence of fibre reinforcement in concrete has an inhibiting effect on the propagation of cracks and contributes to a reduction in stress concentration in places where defects and structural discontinuities occur. The level of critical stress $\sigma_{\mathrm{cr}}$ in the fibre-reinforced concretes was found to be substantial, amounting to $0.80 \sigma_{c} / f_{c}$ for the concrete containing $1 \%$ of steel fibres and to $0.81 \sigma_{c} / f_{c}$ for the concrete containing $3 \%$ of steel fibres. It was higher than that in the reference concrete without fibre reinforcement, amounting to $0.78 \sigma_{c} / f_{c}$. The experimental results presented by Przybylska-Fałek (2013) seem to indicate that in fibrereinforced concretes the level of cracking initiating stress $\sigma_{\mathrm{i}}$ is equal to the level of critical stress.

\subsection{Self-compacting concrete}

The novelty of this special concrete consists in the selfcompaction of the concrete mixture whereby its mechanical compaction during placing has been completely eliminated (Kaszyńska 2012; Neville 2000; Okamura et al. 2005; Okamura, Ouchi 1991, 2003). The selfcompactability of concrete mixture is obtained through the use of appropriate additions and admixtures, combined with the proper selection of the other components (Gorzelańczyk, Hoła 2011; Holschemacher 2004; Kaszyńska 2012; Li, Hwang 2003; ŁaźniewskaPiekarczyk 2012; Nagamoto, Ozawa 1999). Generally, in comparison with ordinary concrete, self-compacting concrete contains more dusty fractions and less coarse aggregate, as well as new-generation superplasticizers endowing the mixture with the required liquidity (Gorzelańczyk, Hoła 2011; Holschemacher 2004; Nagamoto, Ozawa 1999; Okamura, Ouchi 1991, 2003).

It appears from Gorzelańczyk $(2007,2011)$ that the stress failure of self-compacting concretes under compression takes place in three stages. The values of cracking initiating stress $\sigma_{i}$ in such concretes, determined by the acoustic emission technique and the ultrasonic technique, are in an interval of $0.24-0.38 \sigma_{c} / f_{c}$, while the values of critical stress $\sigma_{c r}$ are in an interval of 0.84 $0.93 \sigma_{c} / f_{c}$, as shown in Figure 5.

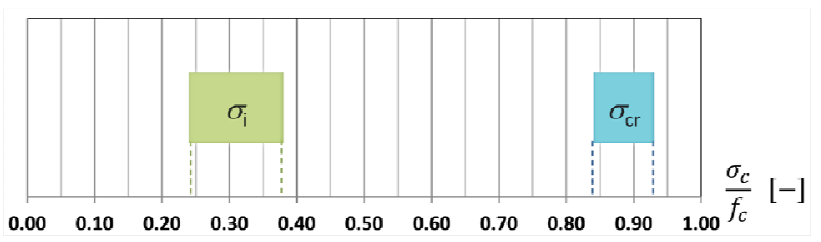

Fig. 5. Intervals of cracking initiating stress $\sigma_{i}$ and critical stress $\sigma_{c r}$ levels in self-compacting concretes

Studies (Gorzelańczyk 2007, 2011) also showed that similarly as in ordinary concretes, moisture content has a significant influence on the level of cracking initiating stress $\sigma_{i}$ in self-compacting concretes. Taking concretes curing in a climatic chamber, in which the level of stress $\sigma_{i}$ is in an interval of $0.30-0.38 \sigma_{c} / f_{c}$, as the reference, as the moisture content in the concrete increases, the mean level of stress $\sigma_{i}$ decreases and at full saturation with water it is in an interval of $0.24-0.26 \sigma_{c} / f_{c}$. A similar dependence is observed when moisture content is reduced from the maximum moisture sorption to the dry condition. Concretes in this moisture condition are characterized by a level of stress $\sigma_{i}$ in an interval of $0.28-0.30 \sigma_{c} / f_{c}$. As regards the level of stress $\sigma_{c r}$, the studies (Gorzelańczyk $2007,2011)$ showed that in the tested concretes the moisture content had little influence on this level.

The above findings are illustrated in Figures 6 and 7 . Figure 6 shows the rate of $\mathrm{AE}$ events $\left(N_{\mathrm{ev}}\right)$ together with a graph of the increment in the relative value of compressive stress $\sigma_{c} / f_{c}$ as a function of failure time for a selected self-compacting concrete damp to different degrees. For the same concrete Figure 7 shows the change in the velocity of longitudinal ultrasonic waves as a function of the increment in the relative value of stress $\sigma_{c} / f_{c}$.

\subsection{High-performance concrete}

High-performance concrete after 28 days of curing is characterized by a compression strength of at least $60 \mathrm{MPa}$ and high durability combined with high tightness (Neville 2000). The best way of obtaining such concrete is through shaping a tight structure of the cement paste by 


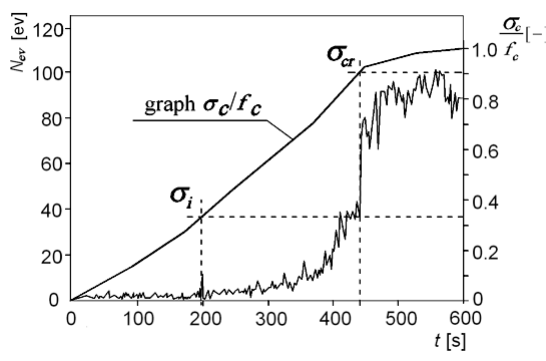

a)

Fig. 6. Rate of AE events $\left(N_{e v}\right)$ versus failure
crete; c) concrete fully saturated with water

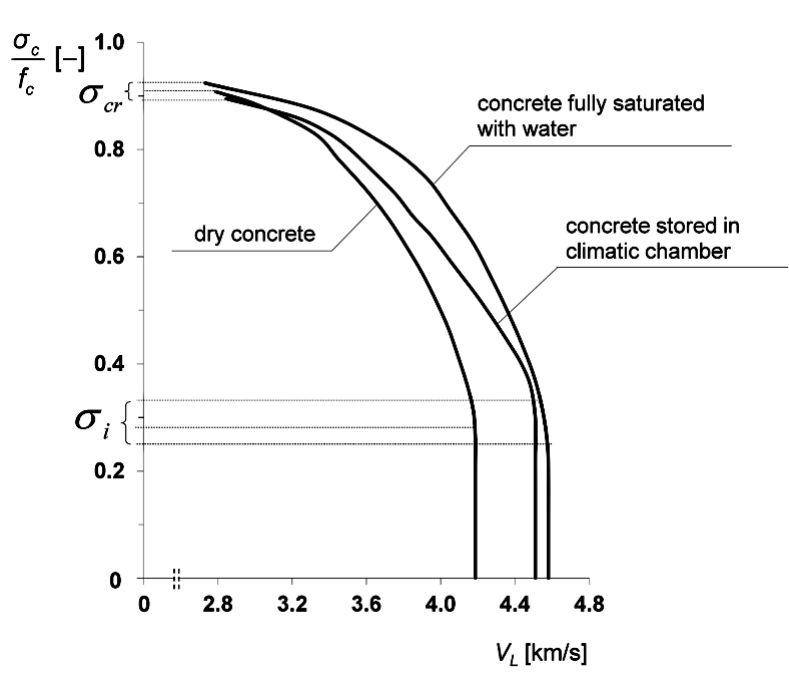

Fig. 7. Change in velocity of longitudinal ultrasonic waves in self-compacting concretes under compression versus increment in relative value of stress

reducing the water/cement ratio with additions strongly plasticizing the concrete mixture and by sealing micropores by introducing a micrograin phase into the grain size distribution. Such microfillers as silica fumes, fly ash, ground granulated slag, metakaolin and other mineral components are used (Hoła 1998, 2000b; Neville 2000; Ngab et al. 1981). High-performance concrete is characterized by a highly strong dense cement matrix well bound with the surface of the aggregate particles. Owing to the high homogeneity of its structure and the lack of weak spots (air voids produced by gravitational water or bleeding) and shrinkage cracks the behaviour of highperformance concrete is radically different from that of ordinary concrete.

The available literature data seem to indicate that the stress failure of high-performance concretes takes place in three stages (Hoła 1998, 2000a, b). However, it was found that in the failure of such concretes it is rather difficult to distinguish the stage of the stable initiation of microcracks from the stage of the unstable propagation of microcracks since the acoustic activity of HPCs under compression is very low in the stress interval covering the two stages. This is undoubtedly due to the much smaller amount of microcracks arising and developing in the course of the failure stages in comparison with ordinary concrete. On the other hand, the final stage is very clearly visible in the failure of high-performance concretes, manifesting itself in the rapidly growing values of the AE descriptors being recorded, as shown in Figure 8 (Hoła 2000b).

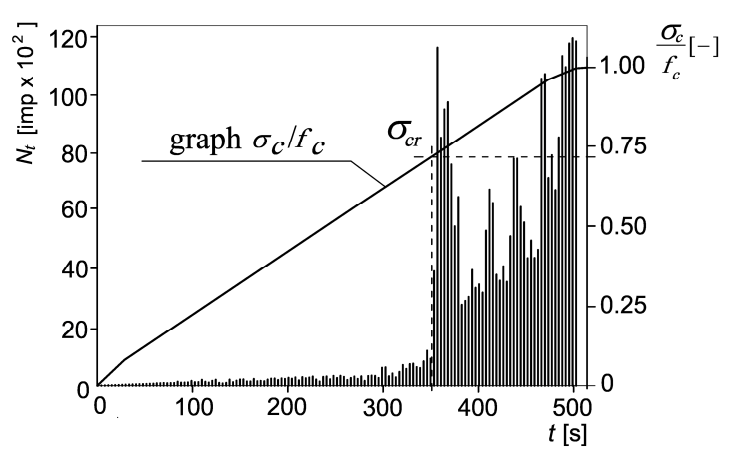

Fig. 8. Typical pattern of rate of $\mathrm{AE}$ events versus failure time for high-performance concrete (Hoła 2000b)

On the basis of literature data (Hoła 1998, 2000a, b) it can be assumed as proven that in high-performance concretes cracking initiating stress $\sigma_{i}$ is within an interval of $0.39-0.56 \sigma_{c} / f_{c}$ while critical stress $\sigma_{c r}$ is within an interval of $0.72-0.86 \sigma_{c} / f_{c}$, as shown in Figures 9 and 10.

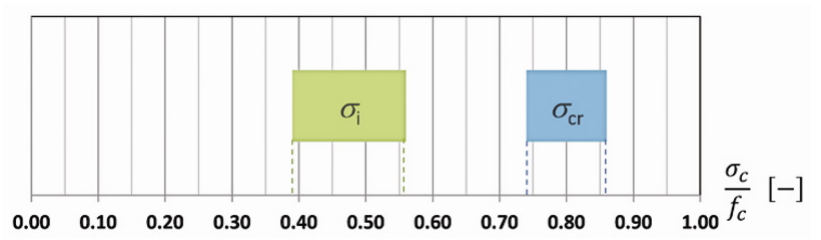

Fig. 9. Initiating stress $\sigma_{l}$ and critical stress $\sigma_{c r}$ intervals in highperformance concretes under compression

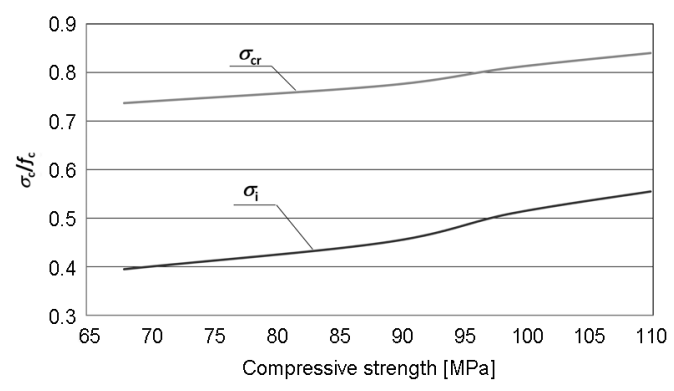

Fig. 10. Levels of cracking initiating stress $\sigma_{i}$ and critical stress $\sigma_{c r}$ in high-performance concretes under compression versus compressive strength 


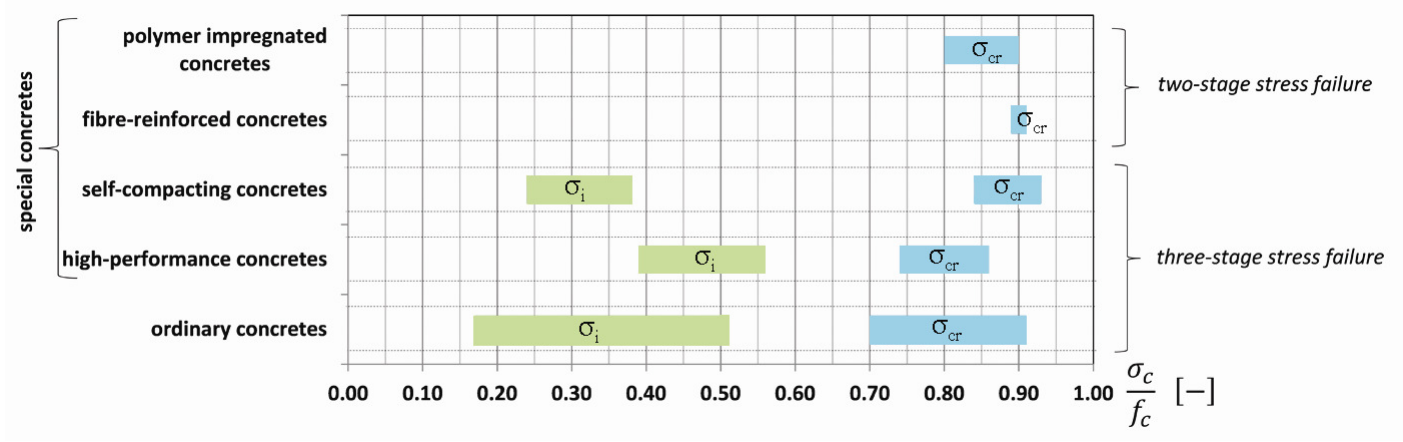

Fig. 11. Cracking initiating stress $\sigma_{i}$ and critical stress $\sigma_{c r}$ intervals in ordinary concretes, high-performance concretes and special concretes

\subsection{Recapitulation}

In order to recapitulate the experimental results on the stress failure of ordinary cement concretes and selected special concretes the intervals of cracking initiating stress $\sigma_{i}$ and critical stress $\sigma_{c r}$ have been collected together in Figure 11. It appears that from among the considered special concretes polymer impregnated concrete and fibre-reinforced concrete are characterized by two-stage stress failure whereas in the case of high-performance concretes and self-compacting concretes stress failure takes place in three stages, similarly as for ordinary concretes.

\section{New-generation concrete}

The most important group of composite materials with a cement matrix today are reactive powder concretes (RPC) belonging to ultra high-performance concretes (UPHC) (Cheyrezy et al. 1995; Czarnecki 2009; Kurdowski et al. 2009; Richard, Cheyrezy 1995; Zdeb, Śliwiński 2009). The production of such materials became possible owing to the advances in the cement binder technology, the availability of highly effective superplasticizing admixtures and the extensive identification of the mechanisms of the action of mineral additions on the microstructure and properties of cementitious materials. The compressive strength of an RPC may be much above $150 \mathrm{MPa}$. According to the available data, Ductal - a concrete produced from reactive powders on an industrial scale - is characterized by a compressive strength of about 250 MPa (Czarnecki 2009; Zdeb, Śliwiński 2009). Reactive powder concretes are the result of many years of research aimed at reducing to minimum the drawbacks of ordinary concrete. They owe their excellent strength properties mainly to:

- the minimized, mainly by reducing the water-binder ratio and simultaneously using highly effective superplasticizers and optionally pressing the mixture in the initial period of cement hydration, porosity of the composite;

- the advantageous modification of the material matrix binder microstructure through proper hydrothermal treatment;
- the increased packing density of the mixture of dry particulate components through the proper selection of their grading;

-the increased homogeneity of the material through the use of only very fine (below $600 \mu \mathrm{m}$ in diameter) aggregate;

-the reduced brittleness of the obtained mature material through the addition of fibre reinforcement with suitable properties, shapes and dimensions.

Figure 12 shows a curve illustrating the evolution of concrete with regard to quality improvement as reflected in the compressive strength of concrete, based on the data found in the literature (Czarnecki 2009) and presented in this paper.

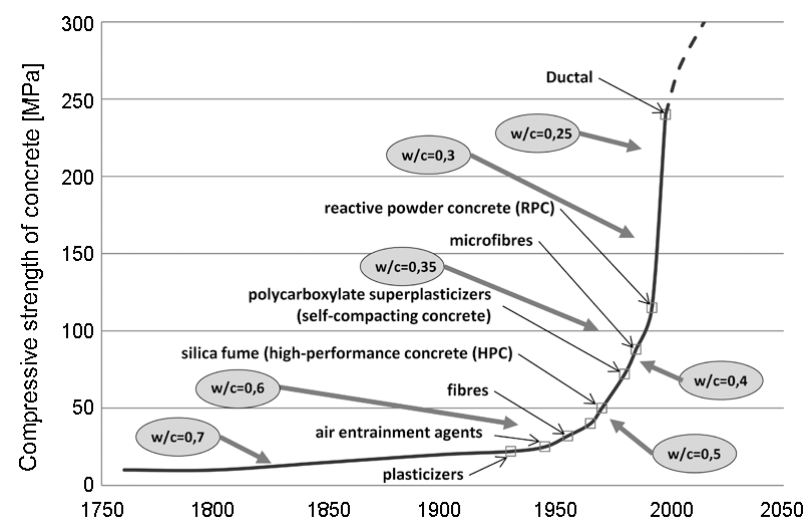

Fig. 12. Curve of concrete evolution (Czarnecki 2009)

The question arises: how does stress failure proceed in reactive powder concrete? So far no reports on this subject have appeared. Undoubtedly, the results of such studies would be very interesting for not only theory, but also practice since such concretes will be increasingly commonly used in the near future.

\section{Example showing how knowledge of stress failure of concrete can be used in practice}

As already mentioned, stress failure manifests itself in cracking initiating stress $\sigma_{i}$ and critical stress $\sigma_{c r}$. It has been demonstrated that the levels of the above stresses in concrete have a bearing on the durability and service safety of structures made of the concrete, under mainly 
sustained cyclic loading (Beres 1971a; Flaga, Furtak 1982; Furtak 1997; Hoła 2000b, 2002; Hsu 1981).

It has been found (Flaga, Furtak 1982; Furtak 1997) that the level of cracking stress $\sigma_{i}$ is equal to the permanent fatigue strength of concrete. It appears from the above studies that stress $\sigma_{c}^{\max }<\sigma_{i}$ does not cause fatigue failure. It is assumed, however, that this is true at number of load cycles $N \leq 10^{7}$ and at cycle asymmetry coefficient $\rho^{f}>0$. It should be noted that if stress $\sigma_{i}<\sigma_{c}^{\max }<\sigma_{c r}$, concrete under compression fails after finite number of cycles $N$ determined by asymmetry coefficient $\rho^{f}$ and the load cycle duration. This kind of failure is referred to as high-cycle fatigue and takes place in two stages. Whereas when stress $\sigma_{c}^{\max }>\sigma_{c r}$, the so-called low-cycle failure of concrete occurs (Flaga, Furtak 1982; Furtak 1997).

Considering the above information and the concretes analyzed in this paper, it should be observed that the visible reduction in the level of stress $\sigma_{\mathrm{cr}}$ in concretes fully saturated with water results in a considerable reduction in their fatigue strength. This observation is of critical importance for the durability and safety of structures subject to sustained cyclic loading or overloads, which may become damp in the course of their service life. On the other hand, a very high level of stress $\sigma_{c r}$ in damp concretes can be regarded as advantageous for their high strength under compression produced by sustained static loading.

For better illustration of the above information, using relation (1) given in Furtak (1997) fatigue strength $f_{c}^{f}$ as a function of number of cycles $N$, assuming cycle asymmetry coefficient $\rho^{f}=0$ and load change frequency $f=1 \mathrm{~Hz}$, was calculated for selected concretes:

$$
f_{c}^{f} / f_{c}=C N^{-A}\left(1+B \rho^{f} \log N\right) C_{f},
$$

where: $C-$ a coefficient expressing a ratio of dynamic strength to static strength under a single loading; $\rho^{f}-\mathrm{a}$ coefficient of cycle asymmetry; $\sigma_{c}^{\min }-$ a minimum cycle stress; $\sigma_{c}^{\max }-$ a maximum stress cycle; $C_{f}-$ a coefficient representing the effect of load change frequency on fatigue strength; $A, B$ - coefficients representing concrete structure condition, through their dependence on the values of stress $\sigma_{i}$ and $\sigma_{c r}$, amounting to respectively:

$$
A=0.008-0.118 \log \left(\sigma_{i} / f_{c}\right), \quad B=0.118\left(\sigma_{c r} / \sigma_{i}-1\right) .
$$
ure 13.

The results of the calculations are shown in Fig-

The following values of cracking initiating stress $\sigma_{i}$ and critical stress $\sigma_{c r}$ were used in the calculations:

- ordinary concrete curing in air-dry condition: $\sigma_{i}=$ 0.42 and $\sigma_{c r}=0.75$ (Hola 2000b);

- ordinary concrete fully saturated with water: $\sigma_{i}=$ 0.20 and $\sigma_{c r}=0.90$ (Hoła 2000b);

-high-performance concrete: $\sigma_{i}=0.51$ and $\sigma_{c r}=0.81$

(Hoła 2000b);

- self-compacting concrete in air-dry condition: $\sigma_{i}=$ 0.38 and $\sigma_{c r}=0.93$ (Gorzelańczyk 2007);
- self-compacting concrete fully saturated with water: $\sigma_{i}=0.25$ and $\sigma_{c r}=0.94$ (Gorzelańczyk 2007);

-steel fibre reinforced concrete: $\sigma_{i}=\sigma_{c r}=0.81$ (Przybylska-Fałek 2013).

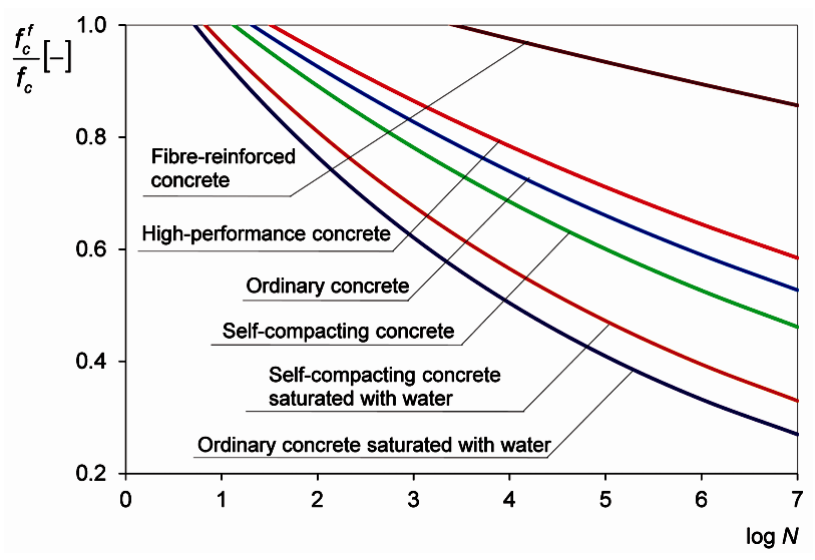

Fig. 13. Fatigue strength versus load cycles, calculated for ordinary concrete, high-performance concrete, self-compacting concrete and fibre-reinforced concrete assuming $\rho^{f}=0$ and $f=1 \mathrm{~Hz}$

The calculated fatigue strength values presented in Figure 13 differ greatly between the analyzed concretes, which is of consequence for building practice. This means that, for example, structural members made of fibre-reinforced concrete, subjected to sustained cyclic loading may fail after a much larger number of cycles than ordinary concrete, high-performance concrete and self-compacting concrete. The calculations also show a marked decrease in the fatigue strength of ordinary concrete and self-compacting concrete, which were fully saturated with water. This is of consequence for building practice since concrete can become damp as a result of, for example, damage to the waterproof insulation of the bridge deck slab.

\section{Conclusions}

1. The stress failure of ordinary concretes under compression takes place in three stages: a stage of the stable initiation of microcracks, a stage of the stable evolution and propagation of the microcracks and a stage of the unstable propagation of microcracks. The length of the particular stages of failure in such concretes depends on the various technological and nonmechanical service factors acting on the concrete. For this reason the relative levels of cracking initiating stress $\sigma_{i}$ and critical stress $\sigma_{c r}$ delimiting the above stages range relatively widely.

2. The stress failure of special concretes under compression takes place in two or three stages for respectively polymer impregnated concretes and steel fibre-reinforced concretes. It has been shown that both the polymer and the fibre reinforcement inhibit the propagation of microcracks until the propagation becomes rapid.

3. From among the concretes considered here, the high-performance concrete is characterized by the 
highest value of cracking initiating stress $\sigma_{i}$. Whereas the self-compacting concrete and the steel fibrereinforced concrete are characterized by the lowest critical stress values.

4. Currently there is no information on the stress failure of new-generation concrete, i.e. reactive powder concrete. Such knowledge would be very useful considering that this type of concrete is likely to be increasingly often used in construction.

5. Finally, it should be noted that many researchers consider cracking initiating stress and critical stress to be the two key strength characteristics of concrete under compression, indicating its predisposition to signalled or unsignalled cracking. Also dependence between the fatigue strength of concrete and the above stresses is observed. Therefore in building practice it is essential to know the values of the stresses since on this basis one can properly evaluate the static-strength performance of a particular concrete in specific structural elements.

\section{References}

Beres, L. 1971a. Fracture of concrete subjected to cyclic and sustained loading, ACI Journal 69(4): 304-305.

Beres, L. 1971b. Relationship of deformational processes and structure change in concrete, in Proc. of International Conference on Structures, Solid Mechanics and Engineering Design in Civil Engineering Materials, 1969, Southampton, London, UK.

Błaszczyński, T. Z. 2011. Assessment of RC structures influenced by crude oil products, Archives of Civil and Mechanical Engineering 11(1): 5-17.

http://dx.doi.org/10.1016/S1644-9665(12)60170-8

Błaszczyński, T.; Przybylska-Fałek, M.; Gorzelańczyk, T.; Hoła, J. 2008. Ocena procesu niszczenia fibrobetonu metodą emisji akustycznej [Fibre reinforced concrete damage process assessment by acoustic emission method], in $\mathrm{Ba}$ dania nieniszczace $w$ diagnostyce technicznej: $37 \mathrm{Kra}$ jowa Konferencja Badań Nieniszczqcych, 21-23 October, 2008, Sobieszewo, Poland, 62-64.

Błaszczyński, T.; Przybylska-Fałek, M.; Hoła, J.; Gorzelańczyk, T. 2009. Fibrobeton jako materiał konstrukcyjny i naprawczy [SFRC as structural and repair material], in M. Kamiński, et al. (Eds). Modern repair methods in buildings and constructions. Wrocław: Dolnośląskie Wydawnictwo Edukacyjne, 96-107.

Broniewski, T.; Hoła, J.; Śliwiński, I. 1994. Application de la méthode démission acoustique aux essais du comportement du béton imprégné de polymère soumis á la compression, Materials and Structures 27(170): 331-337.

Cheyrezy, M.; Maret, V.; Frouin, L. 1995. Microstructural analysis of RPC (Reactive powder concrete), Cement and Concrete Research 25(7): 1491-1500. http://dx.doi.org/10.1016/0008-8846(95)00143-Z

Czarnecki, L. 2009. Polymer concretes, Cement-Wapno-Beton [Cement-Lime-Concrete] 2: 63-85.

Czarnecki, L.; Łukowski, P. 2002. Wpływ domieszek i dodatków polimerowych na trwałość betonu [Influence of polymer admixtures and additives on durability of concrete] in "Days of Concrete - Tradition and Modernity", 2002, Polski Cement, Szczyrk, Poland, 173-200.

Flaga, K. 1993. The influence of stress on the stress destruction and the strength parameters of concrete, in Analytical models and new concepts in mechanics of structural concrete. Białystok: Białystok University of Technology, 55-70.

Flaga, K. 1995. Wpływ naprężeń własnych na destrukcję i parametry wytrzymałościowe betonu [Effect of internal stresses on failure and strength parameters of concrete], Inżynieria i Budownictwo 6: 315-322.

Flaga, K.; Furtak, K. 1981. Influence of aggregate grading on critical stress levels in concrete under compression, Archives of Civil Engineering 27(4): 653-666 (in Polish).

Flaga, K.; Furtak, K. 1982. Effect of aggregate quality on cracking of reinforced concrete beams, Archives of Civil Engineering 28(1-2): 113-133 (in Polish).

Furtak, K. 1997. Wpływ wybranych czynników technologicznych na wytrzymałość zmęczeniową betonu [Influence of some technological factors on fatigue strength of concrete], Cement-Wapno-Beton [Cement-Lime-Concrete] 4: $148-150$.

Furtak, K. 2002. Destrukcja naprężeniowa betonu [Concrete's destruction by stress, Conference], in "Days of Concrete Tradition and Modernity", 2002, Polski Cement, Szczyrk, Poland, 427-439.

Gorzelańczyk, T. 2007. Ocena metodami akustycznymi procesu niszczenia betonów samozagęszczonych [Assessment of the failure of self-compacting concretes by means of acoustic techniques]. Reports of the Institute of Building Engineering at Wrocław University of Technology, PRE Ser., No. 9, Wrocław, Poland. 134 p.

Gorzelańczyk, T. 2011. The effect of moisture content on the failure of self-compacting concrete under compression, as assessed by means of acoustic methods, Archives of Civil and Mechanical Engineering 11(1): 45-60.

Gorzelańczyk, T.; Hoła, J. 2011. Pore structure of self-compacting concretes made using different superplasticizers, Archives of Civil and Mechanical Engineering 11(3): 611-621. http://dx.doi.org/10.1016/S1644-9665(12)60104-6

Goszczyńska, B. 2014. Analysis of the process of crack initiation and evolution in concrete with acoustic emission testing, Archives of Civil and Mechanical Engineering 14(1): 134-143. http://dx.doi.org/10.1016/j.acme.2013.06.002

Holschemacher, K. 2004. Hardened properties of selfcompacting concrete, in Proc. of the $8^{\text {th }}$ International Conference "Modern Building Materials, Structures and Techniques”, 2004, Vilnius, Lithuania, Selected Papers, 55-60.

Hoła, J. 1992a. Effects of aggregate grading on the stress degradation of compressed concrete, Archives of Civil Engineering 38(1-2): 85-101.

Hoła, J. 1992b. Studies on the effect of heat treatment on stress produced in compressed concrete, Engineering Transactions 40(1): 35-36.

Hoła, J.; Ranachowski, Z. 1992. Wykorzystanie metody emisji akustycznej w ocenie wptywu czynników technologicznych $i$ eksploatacyjnych na proces niszczenia betonu [The use of the acoustic emission technique for assessing the influence of technological and service factors on the failure of concrete]. Scientific Papers of the Institute of Fundamental Technological Research at the Polish Academy of Sciences, No. 37, Warsaw.

Hoła, J. 1994. Emisja akustyczna w betonach [Acoustic emission in concretes] in I. Malecki, J. Ranachowski (Eds.). Emisja akustyczna. Źródła, metody, zastosowania [Acoustic emission. Sources, methods and applications]. Warszawa: Polska Akademia Nauk, Instytut Podstawowych Problemów Techniki, 223-240.

Hoła, J. 1996a. Role of thermal treatment in stress failure of concrete differing in its aggregate grain composition, Engineering Transactions 44(1): 17-29. 
Hoła, J. 1996b. Effect of oiling up on the failure of concrete determined by acoustic emission, Archives of Acoustics 21(2): 215-223.

Hoła, J. 1998. Studies of failure of high-strength concrete, Engineering Transactions 46(3-4): 333-351.

Hoła, J. 2000a. Determination of initiating and critical stress levels in compressed plain and high-strength concrete by acoustic methods, Archives of Acoustics 25(1): 57-65.

Hoła, J. 2000b. Naprężenia inicjujace i krytyczne a destrukcja naprężeniowa $w$ betonie ściskanym [Initiating and critical stresses and stress failure in concrete under compression]. Scientific Papers of Institute of Building Engineering at Wrocław University of Technology No. 76, Monograph Series No. 33. Wrocław: Wrocław University of Technology Publishing House. 182 p.

Hoła, J. 2002. Experimentally determined effects of technological and service factors on stress-induced destruction of concrete under compression, Engineering Transactions 50(4): 251-265.

Hsu, T. C. T. 1981. Fatigue of plain concrete, ACI Journal 78(4): 295-305.

Hsu, T. C. T.; Slate, F. O.; Sturman, G. M., Winter, G. 1963. Microcracking of plain concrete and the shape of the stress-strain curve, ACI Journal 60(1): 209-224.

Kaszyńska, M. 2012. Influence of aggregate composition on self-compacting concrete properties, Cement-WapnoBeton [Cement-Lime-Concrete] Special Issue: 57-60.

Khatib, J. M.; Mangat, P. S. 1999. Influence of superplasticizer and curing on porosity and pore structure of cement paste, Cement and Concrete Composites 21(5-6): 431-437. http://dx.doi.org/10.1016/S0958-9465(99)00031-1

Kurdowski, W.; Garbacik, A.; Szelag, H. 2009. The influence of reactive powder types on the properties of concrete of reactive powders, Cement-Wapno-Beton [Cement-LimeConcrete] 6: 292-300.

Li, L.; Hwang, C. 2003. The mixture proportion and property of SCC, in Proc. of the $3^{\text {rd }}$ RILEM Symposium on SelfCompacting Concrete, 2003, Reykjavik, Iceland, 525529.

Łaźniewska-Piekarczyk, B. 2012. The influence of selected new generation admixtures on the workability, air-voids parameters and frost-resistance of Self Compacting Concrete, Construction and Building Materials 31: 310-319. http://dx.doi.org/10.1016/j.conbuildmat.2011.12.107

Moczko, A. 1991. The age effect in cracking behaviour of plain concrete, in A. M. Brandt, L. Marshall (Eds.). Brittle Matrix Composites 3. London: Elsevier Applied Science Publishers, 234-239. http://dx.doi.org/10.1007/978-94-011-3646-4 26

Moczko, A.; Pszonka, A.; Stroeven, P. 1995. Acoustic emission as a useful tool for reflecting cracking behaviour of concrete composites, in International Symposium on NonDestructive Testing in Civil Engineering (NDT-CE), 1995, Berlin, Germany, Vol. 1, 805-811.

Moczko, A. 1996. Emisja akustyczna w badaniach betonu, Inżynieria i Budownictwo [Engineering and Construction] 1: 42-46 (in Polish).

Nagamoto, N.; Ozawa, K. 1999. Mixture properties of SelfCompacting, High-Performance concrete, ACI Materials Journal 172: 623-636.

Neville, A. M. 2000. Properties of concrete. Trans-Atlantic Publications. $846 \mathrm{p}$.

Newman, K.; Newman, J. B. 1971. Failure theories and design criteria for plain concrete, in M. Te'eni (Ed.). Structure, solid mechanics, and engineering design. London: WileyInterscience, 963-996.
Ngab, A. S.; Slate, F. O.; Nilson, A. H. 1981. Microcracking and time-dependent strain in high-strength concrete, $A C I$ Journal Proceedings 78(4): 262-268.

Okamura, H.; Ouchi, M. 1991. Self-compacting concrete: Development, present use and future, in Proc. of the $1^{\text {st }}$ RILEM Symposium on Self-Compacting Concrete, 1999, Stockholm, Sweden, 13-14.

Okamura, H.; Ouchi, M. 2003. Self-compacting concrete, Journal of Advanced Concrete Technology 1(1): 5-15. http://dx.doi.org/10.3151/jact.1.5

Okamura, H.; Maekawa, K.; Mishima, T. 2005. Performance based design for self-compacting structural high-strength concrete, in The $7^{\text {th }}$ International Symposium on the Utilization of High Strength/High-Performance Concrete, 2024 June, 2005, Washington, USA, 13-34.

Perry, C.; Gillott, E. 1977. The influence of mortar-aggregate bond strength on the behaviour of concrete in uniaxial compression, Cement and Concrete Research 7(5): 553564. http://dx.doi.org/10.1016/0008-8846(77)90117-X

Przybylska-Fałek, M. 2013. Ocena procesu niszczenia ściskanych betonów cementowych modyfikowanych stalowym zbrojeniem rozproszonym $z$ uwzględnieniem ścieżki zakrytycznej [Assessment of the failure of cement concretes under compression, modified with steel fibre reinforcements, taking into account the beyond critical path]. Reports of the Department of Building and Environmental Engineering at Poznan University of Technology, Poznań, Poland. $157 \mathrm{p}$.

Ranachowski, Z. 1990. Wyznaczanie naprężeń krytycznych w betonie przy pomocy zautomatyzowanych pomiarów emisji akustycznej [Determination of critical stress in concrete through automated acoustic emission measurements]. Reports of the Institute of Building Engineering at Wrocław University of Technology, Wrocław.

Ranachowski, Z. 1991. Application of acoustic emission method to determine the limit of proportionality and the static strength in concrete, in A. M. Brandt, L. Marshall (Eds.). Brittle Matrix Composites 3. London: Elsevier Applied Science Publishers, 234-239. http://dx.doi.org/10.1007/978-94-011-3646-4 25

Ranachowski, Z. 1997. Metody pomiaru i analiza sygnatu emisji akustycznej [Methods of acoustic emission signal measuring and analysis]. Scientific Papers of the Institute of Fundamental Technological Research at the Polish Academy of Sciences, No. 1, Warsaw.

Ranachowski, Z.; Glinicki, M. A.; Nowowiejski, G. 2010. Application of acoustic emission method for concrete component identification during microhardness testing, $\mathrm{Ce}$ ment-Wapno-Beton [Cement-Lime-Concrete] 4: 202-209.

Ranachowski, Z.; Jóźwiak-Niedźwiedzka, D.; Brandt, A. M.; Dębowski, T. 2012. Application of acoustic emission method to determine critical stress in fibre reinforced mortar beams, Archives of Acoustics 37(3): 261-268. http://dx.doi.org/10.2478/v10168-012-0034-3

Richard, P.; Cheyrezy, M. 1995. Composition of reactive powder concretes, Cement and Concrete Research 25(7): 1501-1511. http://dx.doi.org/10.1016/0008-8846(95)00144-2

Stroeven, P.; Moczko, A. 1996. Assessment of damage evolution stages in cementitious composites by acoustic emission technique, in $2^{\text {nd }}$ International Conference on Nondestructive Testing of Concrete in the Infrastructure, 1996, Nashville, USA, 12-14.

Zdeb, T.; Śliwiński, J. 2009. The influence of selected material and technological factors on mechanical properties and microstructure of reactive powder concrete (RPC), Archives of Civil Engineering 57(2): 227-246. 
Tomasz GORZELAŃCZYK. PhD, Eng, Assistant Professor in the Civil Engineering Faculty at Wrocław University of Technology, Poland. Obtained his diploma in Civil Engineering at WUT in 2001. Currently working at WUT, Institute of Building Engineering. Research interests: concrete (especially self-compacting concrete), failure of concrete, acoustic emission and other non-destructive tests.

Jerzy HOLA. Full Professor at Wrocław University of Technology, Dean of the Faculty of Civil Engineering, Head of the Department of General Building Engineering and Director of the Accredited Research Laboratory at the Institute of Building Engineering. Member of: the Senate of the Wrocław University of Technology, the Council of the Faculty of Civil Engineering, the Section of Engineering Construction Materials and Physics of Construction in the Committee of Civil Engineering at the Polish Academy of Sciences, the Committee of Mechanical Engineering and Civil Engineering at the Polish Academy of Sciences Wrocław, the Science Committee of PZITB (Polish Association of Building Engineers and Technicians), and the Programme Board of the magazine "Builder". 